\title{
240. Studies on Haptoglobin. III
}

\author{
Physicochemical Properties of Hemoglobin-Haptoglobin \\ Complex and Hemoglobin-Antihuman Hemoglobin \\ Antibody Complex. I
}

\author{
By Takehiko SAsazuKI*) and Akio Isomoto**) \\ (Comm. by Tanemoto Furuhata, M. J. A., Dec. 12, 1970)
}

Introduction. Although similarities in molecular structure between haptoglobin ( $\mathrm{Hp}$ ) and antibody were reported, ${ }^{1)-3)}$ many differences in immunochemical properties between these two molecules were also clarified.4),5) Immunological precipitation reaction and complement fixation reaction observed in hemoglobin antihemoglobin antibody interaction were not seen in hemoglobin haptoglobin interaction. ${ }^{4)}$ These immunological differences between hemoglobinhaptoglobin complex (Hb-Hp complex) and hemoglobin-antihemoglobin antibody complex (Hb-Ab complex) lead to the concept that higher structures of $\mathrm{Hb}$ bound by $\mathrm{Hp}$ and that of $\mathrm{Hb}$ bound by antihemoglobin antibody are different from each other. In this communication, differences in higher structure between $\mathrm{Hb}-\mathrm{Hp}$ complex and $\mathrm{Hb}-\mathrm{Ab}$ complex were discussed from the data on circular dichroism spectra (CD spectra) of these two complexes.

Materials and methods. Preparation of Hb-Hp 2-1 complex. Hb-Hp 2-1 complex was prepared by the method of Hamaguchi ${ }^{2}$ with some modification in column size. The purified complex was passed through Sephadex G-25 column equilibrated with $0.05 \mathrm{MI}$ sodium phosphate buffer, $\mathrm{pH}$ 7.0.

Purification of soluble $H b-A b$ complex. Specific antibody to $\mathrm{Hb} \mathrm{A}_{1}$ was purified by using immunoadsorbent described by Avrameas and Ternynck. ${ }^{6)}$ The purified antihemoglobin antibody was added to an excess of purified $\mathrm{Hb} \mathrm{A}_{1}$ to form soluble $\mathrm{Hb}-\mathrm{Ab}$ complex. This clear solution was concentrated to $10 \mathrm{ml}$ by evacuating in a collodion bag and $\mathrm{Hb}-\mathrm{Ab}$ complex was separated from free $\mathrm{Hb} \mathrm{A}_{1}$ by gel filtration through Sepharose $6 \mathrm{~B}$ column, $1.2 \times 70 \mathrm{~cm}$, equilibrated with $0.05 \mathrm{M}$ sodium phosphate buffer, $\mathrm{pH}$ 7.0.

$C D$ spectra of $H b, H b-H p$ complex, and $H b-A b$ complex. CD measurements were performed at $25^{\circ}$ using a Jouan Dichrograph II.

*) Department of Clinical Genetics, Institute of Medical Genetics, School of Medicine, Tokyo Medical and Dental University, Tokyo.

**) Department of Health and Physical Education, College of General Education, Osaka University, Toyonaka. 
The heme concentration of these three samples was 50-150 $\mu \mathrm{M}$. Molar ellipticities are given on a heme basis.

Results and discussion. Figure 1 shows the visible CD spectra of oxy $\mathrm{Hb}-\mathrm{Hp}$ complex, oxy $\mathrm{Hb} \mathrm{A}$, and oxy $\mathrm{Hb}-\mathrm{Ab}$ complex. A through near $520 \mathrm{~m} \mu$ is positive for $\mathrm{Hb}-\mathrm{Hp}$ complex whereas it is negative for $\mathrm{Hb} \mathrm{A}$ and for $\mathrm{Hb}-\mathrm{Ab}$ complex. And the negative of the trough is greater for $\mathrm{Hb}-\mathrm{Ab}$ complex than for $\mathrm{Hb} \mathrm{A}$. Intensity ratio of the positive band at $578 \mathrm{~m} \mu$, and at $546 \mathrm{~m} \mu$ is greater for $\mathrm{Hb}-\mathrm{Hp}$ complex than for Hb-Ab complex, and the greatest for $\mathrm{Hb} \mathrm{A}$. In Fig. 2, CD spectra of these oxygenated compounds in a region from 240 to $450 \mathrm{~m} \mu$ are shown. Just as seen in the region at $520 \mathrm{~m} \mu$, negative

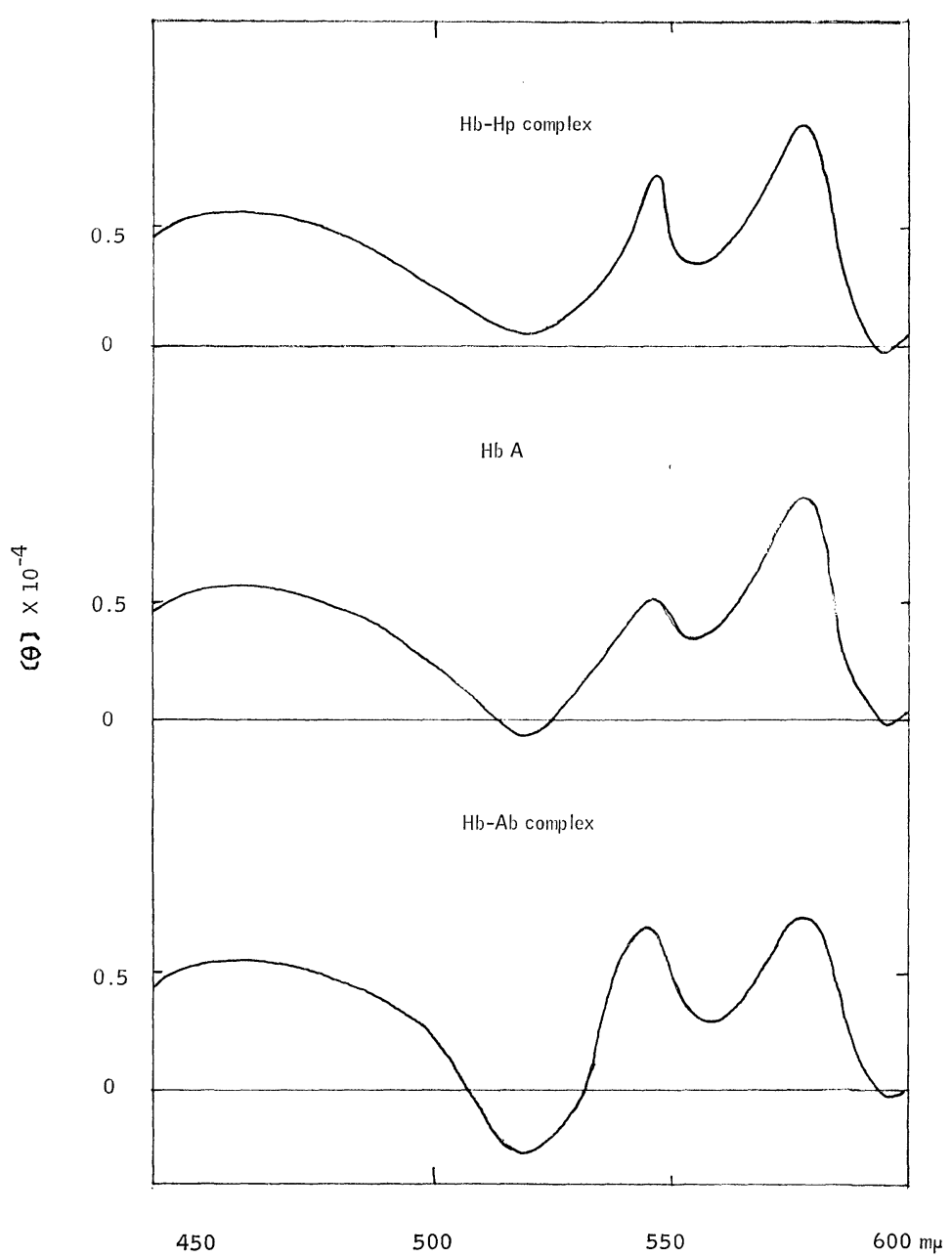

Fig. 1. The visible circular dichroism spectra of $\mathrm{Hb} \mathrm{A}, \mathrm{Hb}-\mathrm{Hp}$ complex, and $\mathrm{Hb}-\mathrm{Ab}$ complex in $0.05 \mathrm{M}$ sodium phosphate buffer, $\mathrm{pH} 7.0$, at $25^{\circ}$. 


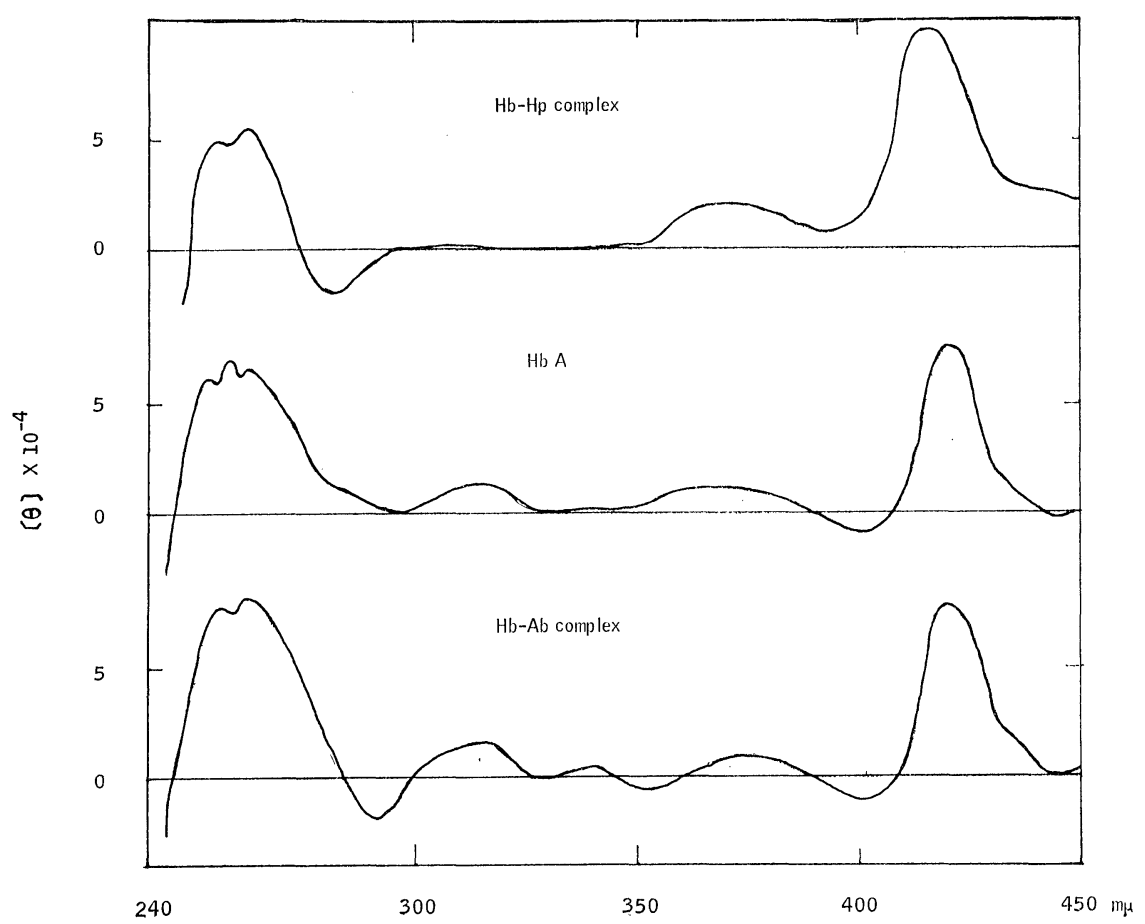

Fig. 2. The circular dichroism spectra of $\mathrm{Hb} \mathrm{A}, \mathrm{Hb}-\mathrm{Hp}$ complex, and $\mathrm{Hb}-\mathrm{Ab}$ complex between $240 \mathrm{~m} \mu$ and $450 \mathrm{~m} \mu$ in $0.05 \mathrm{M}$ sodium phosphate buffer, $\mathrm{pH} 7.0$ at $25^{\circ}$.

troughs are observed for both $\mathrm{Hb} \mathrm{A}$ and $\mathrm{Hb}-\mathrm{Ab}$ complex in the $400 \mathrm{~m} \mu$ region and the corresponding trough for $\mathrm{Hb}-\mathrm{Hp}$ complex is positive. Intensity of the prominent positive band at $420 \mathrm{~m} \mu$ seems to be similar among three compounds in these conditions. A negative trough around $280 \mathrm{~m} \mu$ seen in $\mathrm{Hb}-\mathrm{Hp}$ complex is thought to be a simple effect of $\mathrm{Hp}$ which has a negative trough at around $280 \mathrm{~m} \mu{ }^{7)}$ The same negative trough just as seen in $\mathrm{Hb}-\mathrm{Hp}$ complex but not in $\mathrm{Hb} \mathrm{A}$ is observed in $\mathrm{Hb}-\mathrm{Ab}$ complex at around $280 \mathrm{~m} \mu$. The principal band at $260 \mathrm{~m} \mu$ can be resolved into three positive bands for $\mathrm{Hb} \mathrm{A}$, and into two positive bands for both $\mathrm{Hb}-\mathrm{Hp}$ complex and $\mathrm{Hb}-\mathrm{Ab}$ complex.

From these observations, differences in environmental structure around the heme between $\mathrm{Hb}-\mathrm{Ab}$ complex and $\mathrm{Hb}-\mathrm{Hp}$ complex are clarified which may have some connection with the differences in immunochemical reactions between these two complexes.

Summary. Soluble hemoglobin-antihemoglobin antibody complex ( $\mathrm{Hb}-\mathrm{Ab}$ complex) was purified. Circular dichroism spectra of $\mathrm{Hb} \mathrm{A}, \mathrm{Hb}-\mathrm{Hp}$ complex, and $\mathrm{Hb}-\mathrm{Ab}$ complex were measured and the differences in higher structure of these two complexes were discussed 
in connection with the differences in their immunochemical properties.

Acknowledgement. The authors are deeply indebted to Professor Hiroshi Nakajima for his valuable advices and criticism throughout the course of this work, and to the Biochemical Research Center of Osaka University Medical School for using the facilities.

\section{References}

1) Black, J. A., and Dixon, G. H.: Nature, 218, 736 (1968).

2) Hamaguchi, H.: Amer. J. Hum. Genet., 21, 440 (1969).

3) Haupt, H., and Heide, K.: Blut, Band XX, Heft 1, 1 (1970).

4) Sasazuki, T.: Proc. Japan Acad., 46, 820 (1970).

5) —-: Proc. Japan Acad., 46, 971-973 (1970).

6) Avrameas, S., and Ternynck, T.: Immunochemistry, 6, 53 (1969).

7) Hamaguchi, H., Isomoto, A., and Nakajima, H.: Biochem. Biophys. Res. Commun., 35, 6 (1969). 